\title{
Sensitivity of Monilinia fructicola from Brazil to Tebuconazole, Azoxystrobin, and Thiophanate-Methyl and Implications for Disease Management
}

Louise L. May-De Mio, Department of Crop Protection, Federal University of Paraná, Curitiba, R. Funcionários, 1540, 80.035-050, Brazil; and Yong Luo and Themis J. Michailides, Department of Plant Pathology, University of California-Davis, Kearney Agricultural Center, Parlier 93648

\begin{abstract}
May-De Mio, L. L., Luo, Y., and Michailides, T. J. 2011. Sensitivity of Monilinia fructicola from Brazil to tebuconazole, azoxystrobin, and thiophanate-methyl and implications for disease management. Plant Dis. 95:821-827.

The aim of this study was to investigate the sensitivity of Monilinia fructicola isolates to tebuconazole (demethylation inhibitor [DMI]), azoxystrobin (quinone outside inhibitor), and thiophanate-methyl (methyl benzimidazole carbamate) in 118 isolates collected from four states in Brazil from orchards with different histories of fungicide use. Sensitivity to fungicides was determined by inhibition of mycelial growth and spore germination on fungicide-amended media. Polymerase chain reaction was used to determine the frequencies of $M$. fructicola genotypes exhibiting high (HR) and low (LR) resistance to thiophanate-methyl among sampled populations. Resistance to tebuconazole was found in $15.8 \%$ of isolates collected from São Paulo

to greater than $100 \mu \mathrm{g} / \mathrm{ml}$. The $\mathrm{EC}_{50}$ values for tebuconazole corresponded to its historic use frequency in the orchard; for instance, isolates from orchards with no DMI fungicide use had the lowest mean $\mathrm{EC}_{50}$ value $(0.04 \mu \mathrm{g} / \mathrm{ml})$, while those collected from orchards where more than five DMI fungicide sprays were applied per season had a mean $\mathrm{EC}_{50}$ value of $21.17 \mu \mathrm{g} / \mathrm{ml}$. All isolates were sensitive to azoxystrobin but their $\mathrm{EC}_{50}$, based on tests of inhibition of conidial germination, increased from 0.05 in 2002 to $0.44 \mu \mathrm{g} / \mathrm{ml}$ in 2008 . The $\mathrm{EC}_{50}$ values based on mycelial growth inhibition for thiophanate-methyl were $>162 \mu \mathrm{g} / \mathrm{ml}, 1.99$ to $12.5 \mu \mathrm{g} / \mathrm{ml}$, and $<1.0 \mu \mathrm{g} / \mathrm{ml}$ for $\mathrm{HR}, \mathrm{LR}$, and sensitive isolates, respectively.
\end{abstract} State. The $50 \%$ effective concentration $\left(\mathrm{EC}_{50}\right)$ values varied from 0.01
Stone fruit (nectarine, peach, and plum) are grown on about 22,000 ha in Brazil (11), located mainly in the southern states of Paraná (PR), Santa Catarina (SC), and Rio Grande do Sul (RS) and the southeastern state of São Paulo (SP). The products are marketed as fresh fruit from September to January, depending on the cultivar and where the fruit are produced. Fruit for processing are mainly produced in Pelotas County of RS, while fresh fruit are produced in all of the aforementioned states.

Stone fruit production in Brazil is threatened by blossom blight and fruit rot caused by the ascomycete fungus Monilinia fructicola (G. Winter) Honey $(18,20)$. Fungicide sprays are usually used to control this disease in commercial peach orchards of Brazil. A grower may apply three fungicide sprays during bloom and three more before harvest. However, the number of sprays per season may differ depending on weather conditions and location (18). Most Brazilian stone fruit growers in SP use quinone outside inhibitor (QoI) fungicides alternated with demethylation inhibitor (DMI) fungicides as part of their disease management program. They also continue to apply these fungicides after harvest to control peach rust caused by Tranzschelia discolor (1). Some peach producers use iprodione, procymidone, and thiophanate-methyl fungicides at least twice a season.

The frequent use of site-specific fungicides has the potential for fungicide resistance development in $M$. fructicola populations. $M$. fructicola isolates resistant to the methyl benzimidazole carbamate (MBC) fungicide benomyl have been found in the United States $(17,19,32,34)$ and in other countries $(9,23,24)$. Although benomyl was withdrawn from the market in 1992, stone fruit growers in Brazil and elsewhere have the option to use thiophanate-methyl,

Corresponding authors: L. L. May-De Mio, E-mail: maydemio@ufpr.br T. J. Michailides, E-mail: themis@uckac.edu

Accepted for publication 26 February 2011.

doi:10.1094/PDIS-07-10-0511

(C) 2011 The American Phytopathological Society another MBC, as a replacement for benomyl. DMI fungicide resistance has been detected in M. fructicola isolates from commercial peach orchards in Georgia (25), South Carolina, Ohio, New York, and New Jersey $(5,14)$ but not in California $(31)$. With respect to QoI fungicides, Amiri et al. (2) observed a shift toward reduced sensitivity to azoxystrobin after a comparison between isolate populations from 2006 and 2008. Where QoI use is frequent and selective pressure is high, the sensitivity of isolates may change over time, as was recently determined in other pathosystems $(12,33)$, including fungal pathogens of perennial crops (3).

It is not clear whether M. fructicola has developed fungicide resistance in light of the aforementioned frequent use of site-specific fungicides for blossom blight and fruit brown rot control in commercial peach orchards in Brazil. Thus, the objectives of this study were to determine the sensitivity of $M$. fructicola isolates from Brazil to the DMI fungicide tebuconazole, QoI fungicide azoxystrobin, and MBC fungicide thiophanate-methyl. Furthermore, isolates resistant to thiophanate-methyl were characterized on a molecular level.

\section{Materials and Methods}

Isolates. In total, 118 isolates of M. fructicola were collected from spring of 2000 to fall of 2008 from blossoms, twig cankers, symptomatic mature fruit, and mummified fruit in peach, nectarine, and plum orchards. The isolates were identified to the species level as described previously (7) and came from four states in Brazil: 29 from SP, 30 from PR, 29 from SC, and 30 from RS (Fig. 1). To obtain single-spore isolates, a drop of a spore suspension (approximately $10^{6}$ conidia/ml) of each isolate was streaked onto a 90$\mathrm{mm}$ petri dish containing acidified $(2.5 \mathrm{ml}$ of $25 \%$ [vol/vol] lactic acid per liter) potato dextrose agar (PDA-LA) (Microtech Scientific, Vista, CA). The petri dishes were incubated at 23 to $25^{\circ} \mathrm{C}$ for 1 day and single germinated conidia were transferred onto a fresh PDA-LA petri dish with the aid of a dissecting microscope $(\times 20$ magnification). Each isolate was stored in form of mycelial plugs in sterile water at $4^{\circ} \mathrm{C}$ until use (6).

Survey of fungicide sensitivity. All 118 isolates of $M$. fructicola were tested for sensitivity to tebuconazole, azoxystrobin, and 
thiophanate-methyl. Technical-grade tebuconazole (a.i. 97.5\%; Bayer Corporation, Kansas City, MO) was dissolved in 100\% ethanol, adjusted to a concentration of $10 \mathrm{mg}$ a.i./ml, and added to PDA-LA cooled to $45^{\circ} \mathrm{C}$ after sterilization to produce final tebuconazole concentrations of $0,0.005,0.015,0.045,0.135,0.405$, and $1.2 \mu \mathrm{g} / \mathrm{ml}$. A 4-mm mycelial plug of each isolate was removed from the edge of a 6-day-old colony on PDA-LA using a cork borer and placed separately in the center of a PDA-LA petri dish amended with one of the above fungicide concentrations. Two replicate petri dishes per concentration were used for each isolate. The cultures were incubated at $25^{\circ} \mathrm{C}$ for 6 days. The diameter of the colony was measured in two perpendicular directions, and the diameter of the 4-mm original mycelial plug was subtracted. Some isolates showed no significant reduction of growth at the abovementioned fungicide concentrations. These isolates were further retested on media amended with tebuconazole at $0.005,0.015$, $0.045,0.135,0.405,1.2,3.6,10.2$, and $30.6 \mu \mathrm{g} / \mathrm{ml}$.

Technical-grade azoxystrobin (Syngenta Crop Protection, Greensboro, NC) was dissolved in $100 \%$ acetone and adjusted to a concentration of $1 \mathrm{mg} / \mathrm{ml}$. Sensitivity of each isolate to azoxystrobin was determined using a spore germination method (21) on $2 \%$ water agar (WA) medium amended with azoxystrobin at 0 , $0.0125,0.05,0.015,0.45,0.135,0.405$, and $1.2 \mu \mathrm{g} / \mathrm{ml}$. Azoxystrobin and salicylhydroxamic acid (SHAM; 22) were added to autoclaved WA cooled to $45^{\circ} \mathrm{C}$. SHAM (Sigma-Aldrich, St. Louis) was dissolved in $100 \%$ methanol at a concentration of 100 $\mathrm{mg} / \mathrm{ml}$. The concentrations of acetone and methanol in all WA media were $1 \mathrm{ml} /$ liter. This assessment was performed with two subpopulations, using 12 isolates for the first subpopulation (3 for each of the four states) collected in 2008 (4 years after the introduction of azoxystrobin in stone fruit crops), 2 isolates collected in 2002, and 1 in 2004 from orchards with no azoxystrobin spray history (considered baseline isolates). This experiment was repeated twice.

No other baseline isolates of $M$. fructicola were available from Brazil; however, some of the 12 isolates tested (PR 152, PR 157, PR 158, and PR 159) were considered baseline isolates because they were collected before the use of the active ingredient or taken

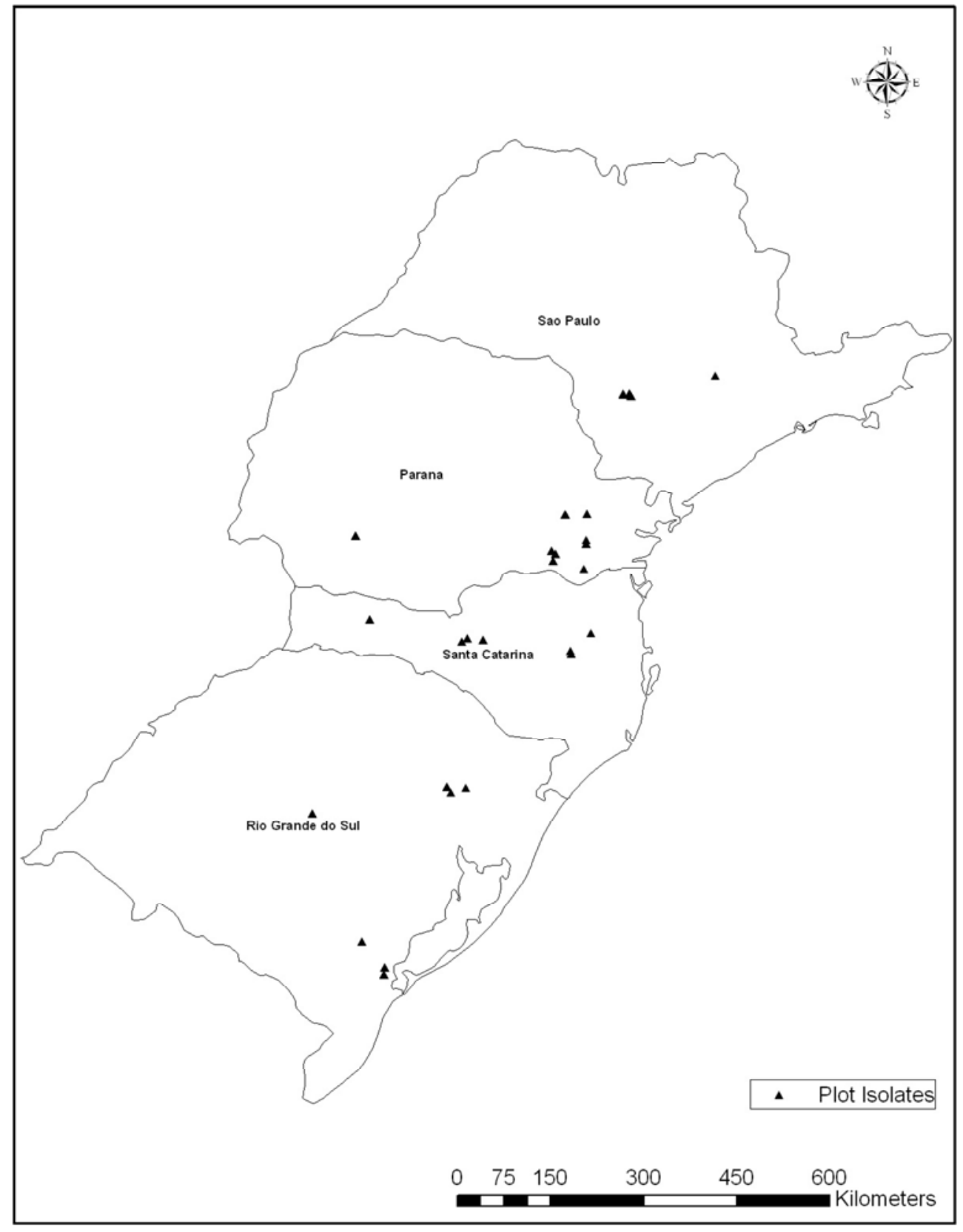

Fig. 1. Map of São Paulo, Parana, Santa Catarina, and Rio Grande do Sul states of Brazil and locations of Monilinia fructicola isolate collection. 
from unsprayed backyard peach trees located $150 \mathrm{~km}$ away from commercial orchards.

Conidial suspensions were prepared in sterile water from 10day-old PDA-LA cultures at $25^{\circ} \mathrm{C}$ and adjusted to $1 \times 10^{4}$ conidia/ml. A $0.1-\mathrm{ml}$ aliquot of the conidial suspension of each isolate was spread on azoxystrobin-amended medium (plus SHAM) and control (with SHAM only) medium. Three petri dishes of each fungicide concentration were used per isolate. After incubating the petri dishes at $25^{\circ} \mathrm{C}$ in darkness for $12 \mathrm{~h}, 100$ conidia per petri dish were examined microscopically and the percentage of germinated conidia was recorded per isolate. The $50 \%$ effective concentration $\left(E_{50}\right)$ value for each isolate was obtained using a linear regression between percentage of inhibition of spore germination and the corresponding $\log 10$ concentrations of the fungicide.

Thiophanate-methyl (Topsin M 70 WP; Elf Atochem North America, Inc., Philadelphia) was suspended in sterile water, adjusted to a concentration of $10 \mathrm{mg} / \mathrm{ml}$, and added to PDA-LA medium at a final concentration of $1 \mu \mathrm{g} / \mathrm{ml}$, the discriminatory dose for sensitive isolates (S). All 118 isolates were tested for high resistance (HR) and isolates that grew in $1 \mu \mathrm{g}$ a.i./ml were tested further for the presence of the E198A mutation (FEA), conferring HR. Primers LRF and LRR2 were used to detect low resistance (LR) as described previously (16). All isolates with HR and $12 \%$ of those with LR were subjected to mycelium growth-inhibition tests using three replicate petri dishes of PDA-LA medium amended with thiophanate-methyl at $0,1,5,10,15,100$, and $500 \mu \mathrm{g} / \mathrm{ml}$ as described above. This experiment was repeated twice and, because equal variances between the two datasets were obtained, the data were combined. Isolates that grew with thiophanate-methyl at 1 $\mathrm{mg} / \mathrm{ml}$ but lacked the allele for LR or HR are referred to as nonsensitive isolates (NS).

DNA extraction from single-spore cultures and detection of resistance alleles. To extract DNA from each of the 118 isolates, mycelium from 7-day-old cultures on PDA-LA medium was transferred to $40 \mathrm{ml}$ of potato dextrose broth (PDB) and incubated for 6 days at $25^{\circ} \mathrm{C}$. Mycelium was harvested, washed with sterile water four times, and dried for $2 \mathrm{~h}$. DNA was extracted using the FastDNA kit by following the manufacturer's guidelines (Biogene Inc., Carlsbad, CA). Polymerase chain reaction (PCR) was performed for all 118 isolates to detect the HR and LR genotype as described previously $(16,17)$.

Data analysis. For each concentration, the inhibition of colony growth $\left(L_{i}\right)$ of isolate $i$ was calculated by $L_{i}=\left(C_{c k}-C_{i}\right) / C_{c k} \times 100$,
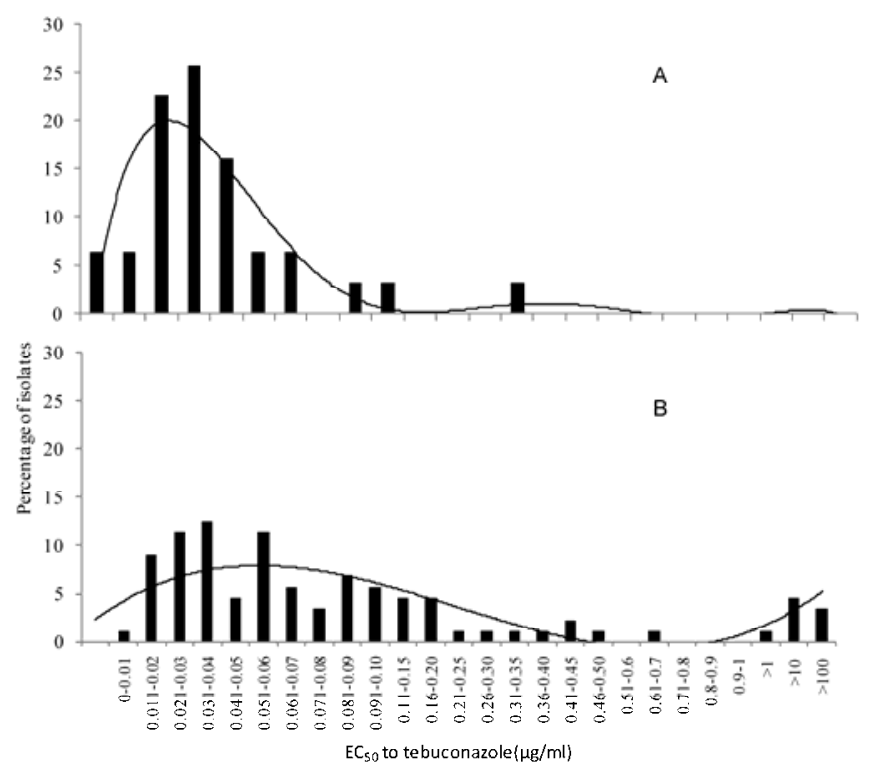

Fig. 2. Distributions of $50 \%$ effective concentration $\left(E_{50}\right)$ values for tebuconazole from A, historic and B, current populations of Monilinia fructicola isolates in Brazil. The Kuiper test (NPAR1WAY procedure of SAS) showed significant difference in the distribution of $\mathrm{EC}_{50}$ values between these two populations $(\mathrm{Ka}=0.001)$. where $C_{c k}$ is the mean colony diameter for the control with no fungicide and $C_{i}$ is the mean colony diameter for isolate $i$. The concentrations of fungicides were $\log 10$ transformed. Linear regressions of the $L$ values on $\log$ concentration of the fungicide were performed with the REG procedure of SAS (version 8.0; SAS Institute, Cary, $\mathrm{NC}$ ). The $\mathrm{EC}_{50}$ value for each fungicide was calculated from the corresponding regression equation for each isolate where the regression coefficient was significant at $P<0.05$.

The $\mathrm{EC}_{50}$ values of Monilinia isolates for tebuconazole were classified into four groups by state, four groups by fungicide spray history with an equal interval, and another group by historical and current population. The fungicide history was defined as follows: no use of fungicide (0 sprays), 1 to 2 sprays per season, 3 to 4 sprays per season, and, more than 5 sprays per season. The isolates of M. fructicola collected from 2000 to 2004 were considered as the historic population while those collected from 2005 to 2008 (when there was an intensive use of tebuconazole started in 2005 in Brazil) were considered as the current population. The arithmetic mean $\mathrm{EC}_{50}$ and the frequency of isolates were calculated for each group. For each fungicide, comparisons were conducted with the NPAR1WAY procedure of SAS using the Kuiper Test to determine significant differences between two distributions of $\mathrm{EC}_{50}$ values, and using median scores $\left(\chi^{2}\right)$ to compare averages among populations collected in different years and different states of Brazil. To compare the $\mathrm{EC}_{50}$ values between the historic and current populations, analysis of variance was conducted and means were compared with the Fisher's least significant difference (LSD) test of SAS (version 8.0; SAS Institute).

\section{Results}

Resistance to tebuconazole and distribution of $\mathrm{EC}_{50}$ values by state and fungicide exposure. The distribution of $\mathrm{EC}_{50}$ values of the 118 isolate population of $M$. fructicola fit the log normal function (Kolmogorov-Smirnov d $=0.23, P<0.01$ ). Only four of the analyzed isolates had $\mathrm{EC}_{50}$ values between 10 and $20 \mu \mathrm{g} / \mathrm{ml}$ while only three isolates had $\mathrm{EC}_{50}$ values $>100 \mu \mathrm{g} / \mathrm{ml}$ (Fig. 2). There was a significant difference $(P \leq 0.001)$ in the mean $\mathrm{EC}_{50}$ value between the historical population of isolates collected from 2000 through 2004 and the current population of isolates collected from 2005 to 2008 . The $\mathrm{EC}_{50}$ values ranged from 0.01 to 0.27 in 31 historical isolates, and from 0.01 to more than $100 \mu \mathrm{g} / \mathrm{ml}$ in 87 current population isolates. The majority $(84 \%)$ of the historical population had $\mathrm{EC}_{50}<0.06 \mu \mathrm{g} / \mathrm{ml}$ as compared with $46.5 \%$ of the current population. In the current population, $15.8 \%$ of the isolates were resistant to tebuconazole (using the discriminatory dose of propiconazole $0.3 \mu \mathrm{g} / \mathrm{ml}$ as described by Cox et al. [8]; Table 1; Fig. 2). The frequency of the historical population was significantly different from the corresponding frequency of the current population (Kuiper test, Ka $<0.001$; Fig. $2 \mathrm{~A}$ and $\mathrm{B}$ ).

The mean $\mathrm{EC}_{50}$ value of 30 isolates from the $\mathrm{SP}$ region was significantly $(P<0.002)$ different from the values of the other three regions; isolates from SC were not different from $\mathrm{PR}(P=0.2443$; Table 2; Fig. 3). Isolates from the $\mathrm{SP}$ region had a mean $\mathrm{EC}_{50}$ value of $16.5 \mu \mathrm{g} / \mathrm{ml}$ and a range of 0.017 to $165 \mu \mathrm{g} / \mathrm{ml}$, compared with isolates from the other regions, which ranged from 0.010 to 0.2

Table 1. Means and ranges of $50 \%$ effective concentration $\left(\mathrm{EC}_{50}\right)$ values to tebuconazole in historic (2000 to 2004) and current (2005 to 2008) populations of Monilinia fructicola isolates collected from stone fruit orchards in Brazil

\begin{tabular}{ccccc}
\hline \multirow{2}{*}{ Population } & \multicolumn{2}{c}{$\mathbf{E C}_{\mathbf{5 0}}(\boldsymbol{\mu g} / \mathbf{m l})$} & $\begin{array}{c}\text { No of } \\
\text { isolates }\end{array}$ & $\begin{array}{c}\text { \% of isolates } \\
\text { resistant }^{\mathbf{z}}\end{array}$ \\
\cline { 2 - 3 } & Mean $^{\mathbf{y}}$ & Range & 31 & 0.0 \\
$2000-2004$ & $0.04 \mathrm{~b}$ & $0.01-0.27$ & 87 & 15.8 \\
\hline
\end{tabular}

y Numbers followed by different letters indicate significant differences at $P$ $=0.001$.

${ }^{\mathrm{z}}$ Percentage of isolates with resistance to tebuconazole $\left(\mathrm{EC}_{50}>0.3 \mu \mathrm{g} / \mathrm{ml}\right)$. Dosage used to discriminate propiconazole resistant from sensitive isolates according to Cox et al. (8). 
(RS) and 0.01 to 0.1 (SC) to 0.014 to $0.5 \mu \mathrm{g} / \mathrm{ml}$ (PR). In SP, resistant isolates were detected at $43 \%$ (13 of 30 isolates) with $\mathrm{EC}_{50}$ greater than $0.3 \mu \mathrm{g} / \mathrm{ml}$, while only $3 \%$ were detected in PR. In RS and $\mathrm{SC}$, no resistant isolates were detected and the maximum $\mathrm{EC}_{50}$ values were 0.2 and $0.1 \mu \mathrm{g} / \mathrm{ml}$, respectively (Fig. 3). The distributions of the isolates among the four regions were very distinct, although the Kuiper Test (used to distinguish two populations for asymptotic distribution) showed that the isolate distribution in SC was not statistically different from that of PR $(P=0.3302$; Table 2; Fig. 3).

The mean $\mathrm{EC}_{50}$ correlated well with the number of fungicide sprays historically applied to the orchard of origin. Values ranged from $0.04 \mu \mathrm{g} / \mathrm{ml}$ for 0 sprays, to $0.06 \mu \mathrm{g} / \mathrm{ml}$ for 1 or 2 sprays per season, to $0.10 \mu \mathrm{g} / \mathrm{ml}$ for 3 to 4 sprays per season, and to 21.17 $\mu \mathrm{g} / \mathrm{ml}$ for areas with more than 5 sprays per season (Table 2; Fig. 4). Comparing the distribution of $\mathrm{EC}_{50}$ values of isolates among the regions, the Kuiper Test demonstrated discrepancy only for more than 5 sprays $(P=0.0001)$ but the mean $\mathrm{EC}_{50}$ values were also different between isolates from orchards with 1 to 2 and those with 3 to 4 sprays ( $P=0.0095$; Table 2; Fig. 4$)$.

Sensitivity of Monilinia isolates to azoxystrobin using spore germination assays. The current (2008) population of isolates showed significantly $(P \leq 0.0001)$ less sensitivity to azoxystrobin compared with the historic population (2002 to 2004), with mean $\mathrm{EC}_{50}$ values of 0.31 and $0.12 \mu \mathrm{g} / \mathrm{ml}$, respectively. Statistical analyses showed that the sensitivity of isolates to azoxystrobin varied among populations in different states (Table 3). Two isolates were used as baseline references (PR100, collected in 2002 and PR 158, collected in 2004), which had $\mathrm{EC}_{50}$ values of 0.05 and $0.13 \mu \mathrm{g} / \mathrm{ml}$, respectively. The 12 isolates that received 1 to 3 sprays per season showed significantly higher $\mathrm{EC}_{50}$ values, ranging from 0.19 to 0.44 $\mu \mathrm{g} / \mathrm{ml}$, compared with the $\mathrm{EC}_{50}$ values of the baseline isolates.

Molecular identification of $\mathrm{MBC}$ resistance alleles and in vitro sensitivity to thiophanate-methyl. In all, 65 of 118 isolates $(54.8 \%)$ were sensitive to thiophanate-methyl. Only $2.5 \%$ of the resistant isolates had the E198A allele conferring HR and $35.9 \%$ were identified as LR with primers LRF and LRR2. Nine resistant isolates did not test positive for any of the two mutations. The $\mathrm{EC}_{50}$ for the HR and LR isolates ranged from 162 to $>500 \mu \mathrm{g} / \mathrm{ml}$ and 1.99 to $12.5 \mu \mathrm{g} / \mathrm{ml}$, respectively (Table 4 ). In total, $80.5 \%$ of SP isolates were sensitive to thiophanate-methyl compared with 34.5 and $56.7 \%$ of the isolates from SC and RS, respectively. One isolate with HR was found in RS and two were found in SP. In the PR region, $0,53.3$, and $46.7 \%$ were $\mathrm{HR}$, LR, and $\mathrm{S}$ isolates. The distri-

Table 2. Mean 50\% effective concentration $\left(\mathrm{EC}_{50}\right)$ values of Monilinia fructicola isolates to tebuconazole and significance values $(P)$ comparing distribution functions and means between populations of isolates classified per locations or number of fungicide sprays per season

\begin{tabular}{|c|c|c|c|c|c|c|c|c|c|}
\hline \multirow{2}{*}{$\begin{array}{l}\text { States of } \\
\text { Brazily }^{\prime}\end{array}$} & \multicolumn{4}{|c|}{ Mean $\mathrm{EC}_{50}(\mu \mathrm{g} / \mathrm{ml})$ and $P$ value between states ${ }^{\mathrm{x}}$} & \multicolumn{5}{|c|}{ Mean $\mathrm{EC}_{50}(\mu \mathrm{g} / \mathrm{ml})$ and $P$ value between fungicide $u^{\mathrm{x}} \mathrm{x}^{\mathrm{x}}$} \\
\hline & SP & $\mathbf{P R}$ & SC & $\mathbf{R S}$ & Sprays $^{\mathbf{z}}$ & $\mathbf{0}$ & 1-2 & 3-4 & $\geq \mathbf{5}$ \\
\hline SP & 16.86 & 0.0003 & 0.0002 & 0.0020 & 0 & 0.04 & 0.7730 & 0.0630 & 0.0001 \\
\hline PR & $(0.0001)$ & 0.06 & 0.2443 & 0.0361 & $1-2$ & $(0.5955)$ & 0.08 & 0.0095 & 0.0001 \\
\hline $\mathrm{SC}$ & $(0.0001)$ & $(0.3302)$ & 0.04 & 0.0035 & $3-4$ & $(0.2791)$ & $(0.0645)$ & 0.10 & 0.0001 \\
\hline RS & $(0.0020)$ & $(0.0101)$ & $(0.0401)$ & 0.07 & $\geq 5$ & $(0.0001)$ & $(0.0001)$ & $(0.0001)$ & 21.17 \\
\hline
\end{tabular}

${ }^{x}$ Numbers in bold represent the mean $\mathrm{EC}_{50}(\mu \mathrm{g} / \mathrm{ml})$ per state or historical fungicide use category. $P$ values in parentheses were estimated with the Kuiper test (Ka) and indicate significance in comparing the population distribution on each state or the population classified based on the number of fungicide applications; $P$ values without parentheses were estimated with a $\chi^{2}$ and indicate significance comparing the means of $\mathrm{EC}_{50}$ in each state or those based on the number of fungicide applications.

y States of Brazil: PR = Paraná, SC = Santa Catarina, SP = São Paulo, and RS = Rio Grande do Sul.

${ }^{\mathrm{z}}$ Number of fungicide sprays per season.
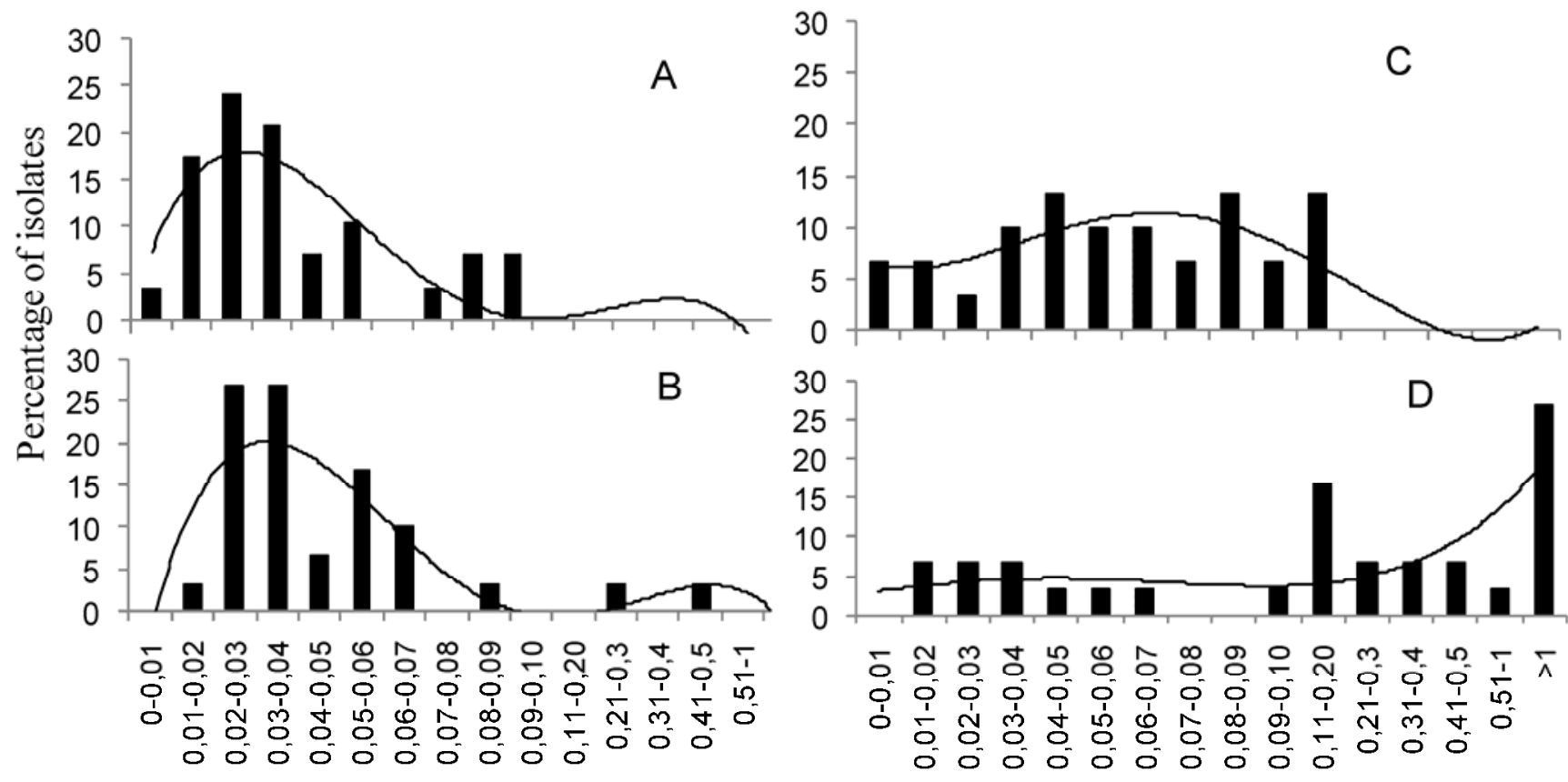

\section{$\mathrm{EC}_{50}$ to tebuconazole $(\mu \mathrm{g} / \mathrm{ml})$}

Fig. 3. Distribution of $50 \%$ effective concentration $\left(E C_{50}\right)$ values for tebuconazole from Monilinia fructicola populations collected from A, Santa Catarina; B, Paraná; C, Rio Grande do Sul; and D, São Paulo. The Kuiper test (NPAR1WAY procedure of SAS) showed significant difference in the distribution of $\mathrm{EC}_{50}$ values between populations (Ka < $0.05)$; except for those between Paraná and Santa Catarina states $(K a=0.3302)$. 
bution of $\mathrm{S}$ isolates between years indicated a steady increase of $\mathrm{S}$ isolates from $20 \%$ in 2000 to $50 \%$ in 2005 , after which the frequencies remained steady (Fig. 5).

\section{Discussion}

The DMI fungicide tebuconazole has been applied in stone fruit orchards to control brown rot caused by Monilinia isolates in the state of SP, Brazil, since 1995 and in other states of Brazil since 2004. Our results indicate a significant increase in the $\mathrm{EC}_{50}$ values for tebuconazole in the current population (2005 to 2008) compared with the $\mathrm{EC}_{50}$ values of the historic populations (2000 to 2004) of $M$. fructicola isolates. These data are in agreement with Zehr et al. (32), who reported that the $\mathrm{EC}_{50}$ values of $M$. fructicola isolates from South Carolina had increased within 3 years after 29 applications of propiconazole, a fungicide with a different active ingredient but that belongs in the same group of fungicides. In contrast, Yoshimura et al. (31) compared two populations of $M$. fructicola from California and found similar $\mathrm{EC}_{50}$ values for tebuconazole in the 1992-to-1998 population compared with isolates collected in 2002.

Reported baseline distributions of $\mathrm{EC}_{50}$ values to triazoles of $M$. fructicola varied with production regions. For example, Wilcox and Burr (30) from New York determined $\mathrm{EC}_{50}$ values for $M$. fructicola ranging from 0.003 to $0.034 \mu \mathrm{g} / \mathrm{ml}$, with a mean of $0.007 \mu \mathrm{g} / \mathrm{ml}$ for tebuconazole; Zehr et al. (32) in South Carolina reported a range of 0.02 to $0.15 \mu \mathrm{g} / \mathrm{ml}$, with a mean of $0.03 \mu \mathrm{g} / \mathrm{ml}$ for propiconazole; and Yoshimura et al. (31) in California reported a range of 0.001 to $0.0607 \mu \mathrm{g} / \mathrm{ml}$ for tebuconazole. Our results show high $\mathrm{EC}_{50}$ values ( 0.01 to $0.27 \mu \mathrm{g} / \mathrm{ml}$ ) for the isolates of the historical population; however, when only the isolates that never had come in contact with the fungicide were considered, the $\mathrm{EC}_{50}$ values were similar $(0.01$ to $0.09 \mu \mathrm{g} / \mathrm{ml})$ to those reported for U.S. populations. Holb and Schnabel (10) reported that a baseline isolate (SDL71.01) collected in 2001 from a peach orchard in South Carolina that had never been exposed to DMIs and was located at least $8 \mathrm{~km}$ away from the nearest commercial orchard was sensitive to propiconazole, tebuconazole, and fenbuconazole, with $\mathrm{EC}_{50}$ values of 0.023 , 0.018 , and $0.019 \mu \mathrm{g} / \mathrm{ml}$, respectively. Our results showed that $15.8 \%$ of the isolates in the current population were resistant to tebuconazole and that the majority of resistant isolates were from $\mathrm{SP}$, where more than five sprays of tebuconazole per season were used. This intensive use of DMI fungicides must have led to an accelerated rate of selection for resistance. Other studies document a slower selection process (25). The reason for this intensive use of tebuconazole in the SP region is that this fungicide is also applied to control peach leaf rust (T. discolor), thus giving a longer period of exposure for $M$. fructicola to the active ingredient of the fungicide, especially because the spray period can sometimes last from spring to early autumn. In some cases, tebuconazole has also been used in other Brazilian states but, in SP, the peach production area is located in a region with subtropical conditions and the weather is

Table 3. Description of Monilinia fructicola isolates, number of sprays of azoxystrobin per season, and the corresponding $50 \%$ effective concentration $\left(\mathrm{EC}_{50}\right)$ values

\begin{tabular}{|c|c|c|c|c|}
\hline \multicolumn{3}{|c|}{ Isolate description } & \multirow[b]{2}{*}{ Applications $^{x}$} & \multirow[b]{2}{*}{$\mathbf{E C}_{50}(\mu \mathrm{g} / \mathrm{ml})^{\mathrm{y}}$} \\
\hline State $^{w}$ & Name & Year & & \\
\hline SP & 346 & 2008 & $>5$ & $0.4475 \mathrm{a}$ \\
\hline PR & 190 & 2008 & $3-4$ & $0.4320 \mathrm{a}$ \\
\hline PR & 186 & 2008 & $1-2$ & $0.2988 \mathrm{~b}$ \\
\hline PR & 185 & 2008 & $1-2$ & $0.2333 \mathrm{c}$ \\
\hline SP & 340 & 2008 & $>5$ & $0.2063 \mathrm{c}$ \\
\hline SP & 347 & 2008 & $>5$ & $0.1920 \mathrm{~cd}$ \\
\hline $\mathrm{SC}$ & 546 & 2008 & $1-2$ & $0.1526 \mathrm{de}$ \\
\hline $\mathrm{SC}$ & 502 & 2008 & ni & 0.1463 ef \\
\hline $\mathrm{SC}$ & 329 & 2008 & ni & $0.1352 \mathrm{ef}$ \\
\hline PR & $158^{z}$ & 2004 & 0 & $0.1317 \mathrm{ef}$ \\
\hline RS & 558 & 2008 & 0 & 0.1310 ef \\
\hline RS & 335 & 2008 & 0 & 0.1177 ef \\
\hline RS & 339 & 2008 & 0 & $0.1049 \mathrm{f}$ \\
\hline PR & $100^{z}$ & 2002 & 0 & $0.0500 \mathrm{e}$ \\
\hline
\end{tabular}

${ }^{\text {w }}$ States of Brazil: PR = Paraná, $\mathrm{SC}=$ Santa Catarina, $\mathrm{SP}=$ São Paulo, and RS $=$ Rio Grande do Sul.

${ }^{x}$ Number of azoxystrobin applications per season.

${ }^{y}$ Different letters indicate significant differences at $P=0.05$.

${ }^{\mathrm{z}}$ Isolates PR 100 (2002) and PR 158 (2004) were considered baseline isolates because they did not come in contact with QoI fungicides in the field.
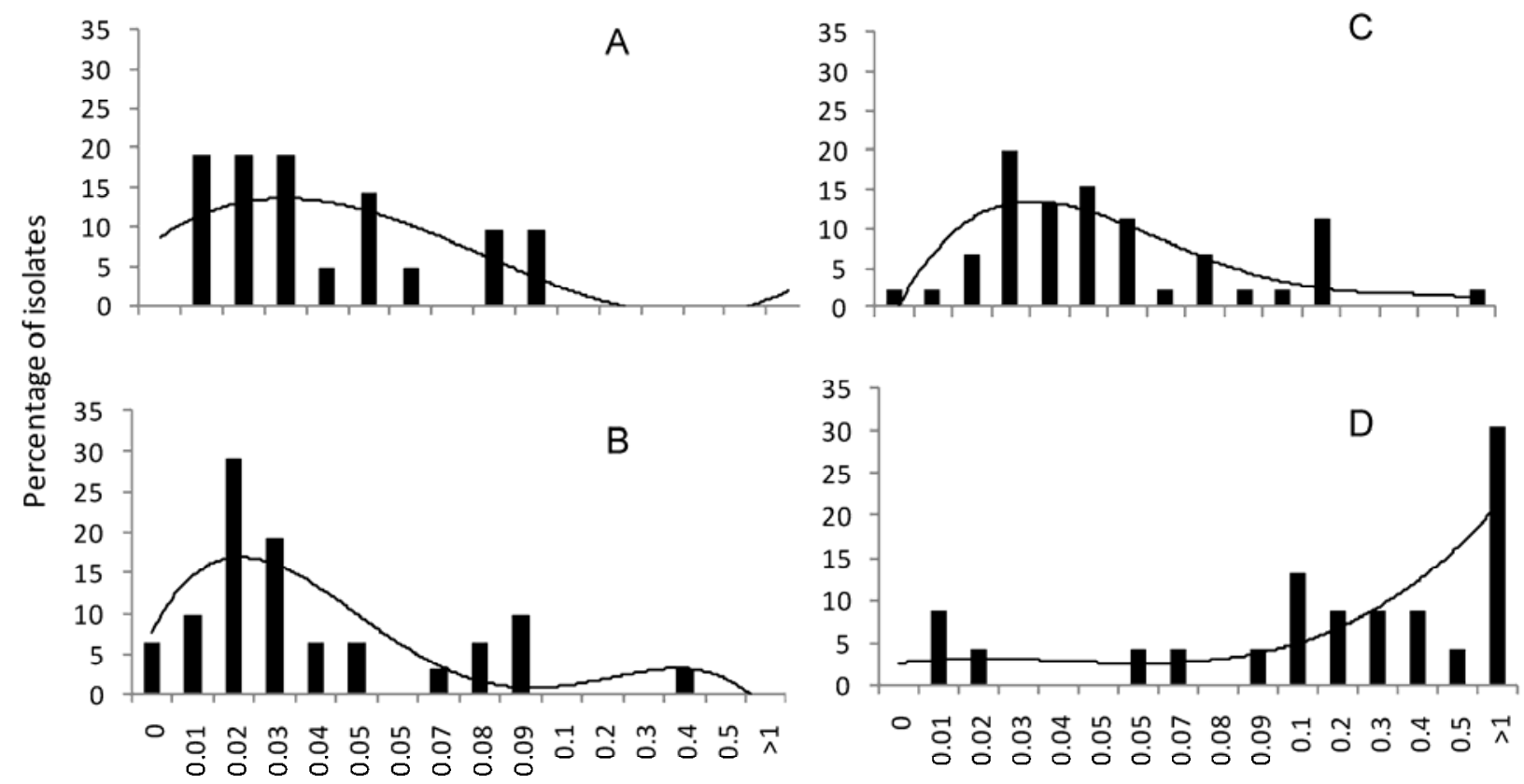

\section{$\mathrm{EC}_{50}$ to tebuconazole $(\mu \mathrm{g} / \mathrm{ml})$}

Fig. 4. Distribution of $50 \%$ effective concentration $\left(E_{50}\right)$ values for tebuconazole from populations of Monilinia fructicola collected from Brazilian stone fruit orchards with $\mathbf{A}$, no fungicide spray; $\mathbf{B}, 1$ to 2 sprays per season; $\mathbf{C}, 3$ to 4 sprays per season; and D, more than 5 sprays per season. The Kuiper test (NPAR1WAY procedure of SAS) showed significant difference in distribution of $\mathrm{EC}_{50}$ values between number of fungicide sprays $(\mathrm{Ka}=0.0001)$. 
hotter than the southern states, making the management of the pathogen ever more intensive than that in the other states.

The distribution of $M$. fructicola isolate populations from Brazilian states seemed to be influenced by the general disease management practiced in peach orchards. For instance, the mean value of $\mathrm{EC}_{50}$ to tebuconazole was high $(16.3 \mu \mathrm{g} / \mathrm{ml})$ for isolates in SP but very low $(0.04$ to $0.07 \mu \mathrm{g} / \mathrm{ml})$ for isolates in the other states. Incidentally, SP is the most northeasterly state (Fig. 1) and has a subtropical to tropical climate, where the fruit production cycle is shorter and the harvest is early in the season, beginning in September and finishing in October. The association of the favorable conditions with several diseases, and the absence of cold, may have contributed to the high brown rot pressure, necessitating frequent fungicide applications. Brannen et al. (4) controlled the DMIinsensitive $M$. fructicola population in Georgia by using two preharvest applications of increased rates of DMI fungicides, or applications of the premixed fungicide Pristine (boscalid plus pyraclostrobin) followed by propiconazole. Although sprays with increased rates of DMI fungicides are recommended for the subtropical conditions in Brazil, there is a major concern over fungicide resistance, which needs to be closely monitored in the near future, mainly because the resistance mechanism to DMI fungicides of isolates of $M$. fructicola from Brazil is not known yet and measures used in other countries with temperate climates may not work. Evaluation of alternating sprays with fungicides with different active ingredient groups, such as guanidine, may provide a means for managing fungicide resistance. Moreira and May-De Mio (20) also reduced brown rot effectively by using iminoctadine Tris albesilate (guanidine group) in peach orchards in southern Brazil. However, no monitoring for resistant isolates has been done under these circumstances.

Although resistance of $M$. fructicola to QoI fungicides was not discovered, some authors have observed a shift in the sensitivity of the isolates over time. Villani and Cox (29) assessed the sensitivity of 236 isolates of M. fructicola from various counties in New York State from 2005 to 2007 to Pristine and found a shift in the sensitivity of these isolates. Amiri et al. (2) investigated QoI resistance from 2006 to 2008 in 157 M. fructicola isolates from South Carolina and Georgia and observed that the mean $\mathrm{EC}_{50}$ values of a number of isolates from these populations to azoxystrobin, pyraclostrobin, and boscalid were significantly higher $(P=0.01)$ than the mean $\mathrm{EC}_{50}$ values of the baseline population, with a four- and threefold increases for boscalid and azoxystrobin, respectively. They concluded that there was a build-up of QoI-resistant isolates among $M$. fructicola populations in commercial peach orchards of the southeastern United States. Our results using the historic (2002 to 2004) populations of Monilinia isolates from Brazil are consistent with the studies mentioned above. The LSD test showed statistically significant differences $(P=0.05)$ between seven isolates from 2008 from orchards where 1 to more than 5 sprays of QoI fungicides were used per season. Luo and Schnabel (15) considered nine isolates of M. fructicola with $\mathrm{EC}_{50}$ varying from 0.05 to $0.14 \mu \mathrm{g} / \mathrm{ml}$ azoxystrobin as sensitive. After mutagenesis, however, some of these isolates became resistant, with $\mathrm{EC}_{50}$ values of 0.2 to $1 \mu \mathrm{g} / \mathrm{ml}$. An azoxystrobin concentration of $3 \mu \mathrm{g} / \mathrm{ml}$ could be considered as discriminatory to distinguish resistant from sensitive isolates. Amiri et al. (2) and Schnabel et al. (26) reported baseline data up to 1.35 $\mu \mathrm{g} / \mathrm{ml}$ to azoxystrobin with SHAM. Using these criteria, in our study, no isolates resistant to azoxystrobin were observed. However, many Brazilian growers continue to use products containing this active ingredient or other fungicides of the same chemical class. Thus, it is necessary to monitor for resistance in the near future. Although we observed a shift of sensitivity for azoxystrobin in a sample of the $M$. fructicola population from Brazil tested in this study, using just two isolates as baseline isolates for this comparison may be too few to make strong conclusions. Future collection of isolates and population comparisons must be considered to better understand the behavior of M. fructicola to the QoI fungicides.

The results of PCR tests showed that the HR Brazilian population of M. fructicola isolates had the E198A allele conferring resistance to benzimidazole fungicides. Although LR isolates were found in populations from all states from 2000 to 2008 , HR was found only in RS and SP states in 2005 and 2007, respectively. Three HR isolates came from the locations where the producers applied more than five sprays of thiophanate-methyl per season. Several reports on benomyl resistance in $M$. fructicola isolates from the United States reported concentrations between 0.5 and 4 $\mu \mathrm{g} / \mathrm{ml}$ conferring resistance to benzimidazole $(13,19,27,28,32)$. Among the isolates tested in this study, the $\mathrm{EC}_{50}$ of insensitive isolates was $>1 \mu \mathrm{g} / \mathrm{ml}$ and those with the HR gene could grow even at $>500 \mu \mathrm{g} / \mathrm{ml}$. Yoshimura et al. (31) reported HR and LR to benzimidazole among $M$. fructicola isolates in California stone fruit orchards with $\mathrm{EC}_{50}$ values of $<2 \mu \mathrm{g} / \mathrm{ml}$ for $\mathrm{S}$ isolates, between 2 and $30 \mu \mathrm{g} / \mathrm{ml}$ for LR isolates, and $>30 \mu \mathrm{g} / \mathrm{ml}$ for the HR isolates. The E198A allele was also found in HR isolates of M. fructicola in California (17), South Carolina (34), and several other countries. Interestingly, some isolates with LR resistance to MBC were not distinguished by using the LRF and LRR2 primers, suggesting another new mechanism of resistance.

In peach production areas of Brazil, the mean number of sprays with benzimidazoles per season in 2000 was 2 to 4 . Starting in

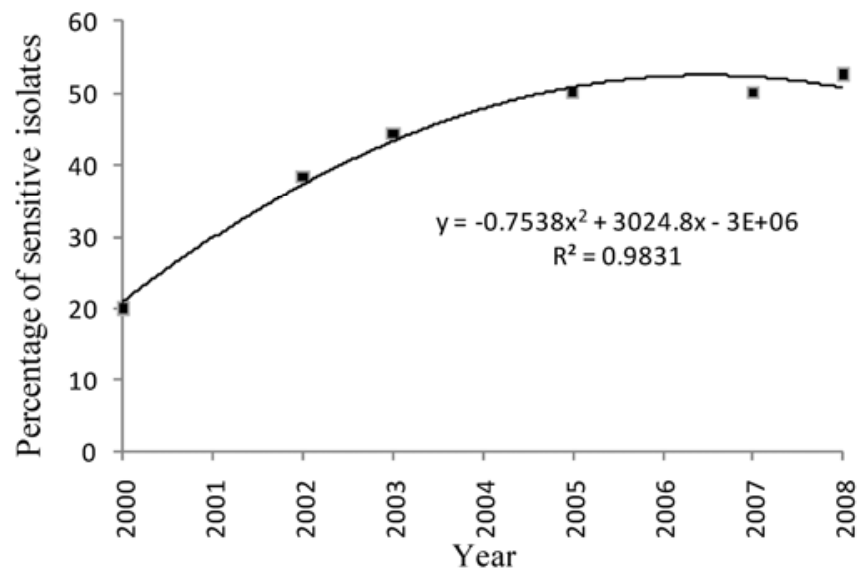

Fig. 5. Percent thiophanate methyl-sensitive isolates of Monilinia fructicola collected from 2000 to 2008. The best fit model was a second-degree polynomial $\left(R^{2}\right.$ $=0.983 ; P<0.05)$

Table 4. Frequencies and $50 \%$ effective concentration $\left(\mathrm{EC}_{50}\right)$ of thiophanate-methyl-sensitive and -resistant Monilinia fructicola isolates collected from four states in Brazil

\begin{tabular}{|c|c|c|c|c|c|c|}
\hline \multirow[b]{2}{*}{ Resistance category ${ }^{y}$} & \multicolumn{4}{|c|}{ Frequency of isolates $(\%) /$ state $^{x}$} & \multirow[b]{2}{*}{ Isolates $(\%)(n=118)$} & \multirow[b]{2}{*}{ EC $_{50}$ value $(\mu \mathrm{g} / \mathrm{ml})^{z}$} \\
\hline & SP & PR & SC & $\mathbf{R S}$ & & \\
\hline HR & 6.5 & 0.0 & 0.0 & 3.3 & 2.5 & $162->500$ \\
\hline LR & 6.5 & 53.3 & 58.6 & 26.7 & 35.9 & $1.99-12.5$ \\
\hline $\mathrm{S}$ & 80.5 & 46.7 & 34.5 & 56.7 & 54.8 & $<1$ \\
\hline NS & 3.2 & 0 & 6.9 & 13.3 & 5.8 & $>1$ \\
\hline
\end{tabular}

${ }^{\mathrm{x}}$ States of Brazil: PR = Paraná and RS = Rio Grande do Sul (30 isolates/state); SC = Santa Catarina and SP = São Paulo (29 isolates/state).

${ }^{\mathrm{y}} \mathrm{HR}=$ isolates with the E198A allele coding for high resistance $\left(\mathrm{EC}_{50} \geq 30 \mu \mathrm{g} / \mathrm{ml}\right), \mathrm{LR}=$ low-resistance isolates $\left(\mathrm{EC}_{50}=1\right.$ to $\left.30 \mu \mathrm{g} / \mathrm{ml}\right), \mathrm{S}=\mathrm{sensitive} \mathrm{iso-}$ lates $\left(\mathrm{EC}_{50}<1 \mu \mathrm{g} / \mathrm{ml}\right)$, and $\mathrm{NS}=$ nonsensitive isolates.

${ }^{\mathrm{z}}$ Range of $\mathrm{EC}_{50}$ values of three HR and five LR isolates. 
2002, the use of these fungicides was drastically reduced in some states (PR, SC, and RS), although some producers (mainly in PR and SC) continued to apply the same number of sprays and fungicides to control other diseases, such as anthracnose of peach caused by Colletotrichum gloeosporioides (Penz.) Penz. \& Sacc. (SP and RS) and peach leaf curl caused by Taphrina deformans (Berk.) Tul. The percentage of isolates sensitive to thiophanatemethyl increased until 2005 and remained steady from 2005 to 2008 (Fig. 5); considering 111 isolates, 4 isolates collected in 2004 and 3 in 2006 were excluded from the analyses because these 7 isolates had not come in contact with any benzimidazole sprays. Interestingly, when isolates were collected from areas where no fungicides had been used in some years, the incidence of sensitive populations increased to $90 \%$ (data not shown). However, in 1996, Moreira and May-De Mio assessed 210 isolates from Lapa County, PR, Brazil in PDA amended with benomyl at $1 \mu \mathrm{g} / \mathrm{ml}$ and observed that $87 \%$ of the isolates grew at the same rate as on PDA with no fungicide (control) (L. M. Moreira and L. L. May-De Mio, unpublished data). In the present study using isolates from the same region (Lapa, PR, 2003 to 2008), 80\% of the isolates were LR and grew at 1 $\mu \mathrm{g} / \mathrm{ml}$. This could indicate stability in the population of Monilinia isolates resistant to benzimidazoles, which is also supported by other studies $(23,24)$. However, special attention should be given to assessing the stability of these populations under field conditions in Brazil by considering other regions and more isolates.

An important consideration for fungicide resistance management is the amount of inoculum. Difficulties in managing brown rot in peach in Brazilian orchards located in subtropical regions, under warm and humid environmental conditions, are due not only to the high risk for developing fungicide resistance but also to the high disease inoculum levels found in the areas of peach production. The efficacy of DMI treatments decreased under high disease levels in peach orchards in Georgia, suggesting that even DMI fungicides cannot provide adequate control if disease pressure is too high (25).

To achieve acceptable brown rot control with fungicide applications, measures to reduce inoculum levels and alternation of active ingredients during the entire season (dormancy, bloom, fruit expansion, and prior to harvest) must be implemented in commercial peach orchards. This is the first report indicating a shift in the sensitivity to QoI fungicides in Monilinia isolates from Brazil and the first report of resistance to thiophanate-methyl and tebuconazole of this pathogen in Brazilian stone fruit orchards.

\section{Acknowledgments}

The isolates used in this study were collected by collaborators of several plant pathology laboratories in Brazil: the Universidade Estadual de São Paulo (ESALQ-USP), Empresa Brasileira de Pesquisa Agropecuária (EMPRAPA: Frutas Temperadas e Uva e Vinho), EPAGRI-Cacador from Santa Catarina, Universidade Federal do Paraná (UFPR), Universidade do Rio Grande do Sul (UFRS), and Universidade Federal de Pelotas (UFPel). We also appreciate the excellent collaboration of peach producers and technicians from extension programs of the Brazilian states. Some of this work was completed during the 2007 sabbatical leave of L. L. May-De Mio at the laboratory of T. J. Michailides at Kearney Agricultural Center.

\section{Literature Cited}

1. Alves, G., and May-De Mio, L. L. 2008. Efeito da desfolha causada pela ferrugem na floração e produtividade do pessegueiro. Rev. Bras. Frutic. 30:907-912.

2. Amiri, A., Brannen, P. M., and Schnabel, G. 2010. Reduced sensitivity in Monilinia fructicola field isolates from South Carolina and Georgia to respiration inhibitor fungicides. Plant Dis. 94:737-743.

3. Baudoin, A., and Baldwin, M. 2006. First report of QoI fungicide resistance of grape downy mildew in North America. (Abstr.) Phytopathology 96:S190.

4. Brannen, P. M., Taylor, K, Hotchkiss, M., Reilly, C, Schnabel, G., and Amiri, A. 2008. Evolving management strategies for Monilinia fructicola populations with reduced sensitivity to DMIs in Georgia and implications for brown rot control recommendations (Abstr.) Phytopathology 98:S25.

5. Burnett, A., Lalancette, N., and McFarland K. 2010. First report of the peach brown rot fungus Monilinia fructicola resistant to demethylation inhibitor fungicides in New Jersey. Plant Dis. 94:126.

6. Castelani, A. 1963. The "water cultivation" of pathogenic fungi. J. Trop. Med. Hyg. 66:283-284.
7. Còté, M. J., M. C. Tardif, and A. J. Meldrum. 2004. Identification of Monilinia fructigena, M. fructicola, M. laxa, and Monilia polystroma on inoculated and naturally infected fruit using Multiplex PCR. Plant Dis. 88:12191225 .

8. Cox, K. D., Bryson, P. K., and Schnabel, G. 2007. Instability of propiconazole resistance and fitness in Monilinia fructicola. Phytopathology 97:448453.

9. Elmer, P. A. G., and Gaunt, R. E. 1994. The biological characteristics of dicarboximide resistant isolates of Monilinia fructicola from New Zealand stone-fruit orchards. Plant Pathol. 43:130-137.

10. Holb, I. J., and Schnabel, G. 2007. Differential effect of triazoles on mycelial growth and disease measurements of Monilinia fructicola isolates with reduced sensitivity to DMI fungicides. Crop Prot. 26:753-759.

11. IBGE, 2007. Instituto Brasileiro de Geografia e Estatística. http://www. ibge.gov.br/home/

12. Jiang, J. H., Ding, L. S., Michailides, T.J., Li, H., and Ma, Z. 2009. Molecular characterization of field azoxystrobin-resistant isolates of Botrytis cinerea. Pestic. Biochem. Physiol. 93:72-76.

13. Jones, A. L., and Ehret, G. R. 1976. Isolation and characterization of benomyl-tolerant strains of Monilinia fructicola. Plant Dis. Rep. 60:765-769.

14. Luo, C. X., Cox, K. D., Amiri, A., and Schnabel, G. 2008. Occurrence and detection of the DMI resistance-associated a genetic element 'Mona' in Monilinia fructicola. Plant Dis. 92:1099-1103.

15. Luo, C. X., and Schnabel, G. 2008. Adaptation to fungicides in Monilinia fructicola isolates with different fungicide resistance phenotypes. Phytopathology 98:230-238.

16. Luo, Y., Ma, Z., and Michailides, T. J. 2007. Quantification of allele E198Ain beta-tubulin conferring benzimidazole resistance in Monilinia fructicola using real-time PCR. Pest Manage. Sci. 63:1178-1184.

17. Ma, Z., Yoshimura, M. A., and Michailides, T. J. 2003. Identification and characterization of benzimidazole resistance in Monilinia fructicola from stone fruit orchards in California. Appl. Environ. Microbiol. 69:7145-7152.

18. May-De Mio, L. L., Moreira, L.M, Monteiro, L. B., and Justiniano, P. R., Jr. 2008. Infecção de Monilinia fructicola no período da floração e incidência de podridão parda em frutos de pessegueiro em dois sistemas de produção. Trop. Plant Pathol. 33:173-180.

19. Michailides, T. J., Ogawa, J. M., and Opgenorth, D. C. 1987. Shift of Monilinia spp. and distribution of isolates sensitive and resistant to benomyl in California prune and apricot orchards. Plant Dis. 71:893-896.

20. Moreira, L. M., and May-De Mio, L. L. 2009. Controle da podridão parda do pessegueiro com fungicidas e fosfitos avaliados em pré e pós-colheita. Ciênc. Agrotec. 33:405-411.

21. Olaya, G., and Holm, A. 2001. Sensitivity of Didymella bryoniae isolates to azoxystrobin. (Abstr.) Phytopathology 91:S67.

22. Olaya, G., Zheng, D., and Köller, W. 1998. Differential responses of germinating Venturia inaequalis conidia to kresoxim-methyl. Pest Manage. Sci. 54:230-236.

23. Penrose, L. J. 1990. Prolonged field persistence of resistance to benomyl in Monilinia fructicola. Crop Prot. 9:190-192.

24. Sanoamuang, N., and Gaunt, R. E. 1995. Persistence and fitness of carbendazim-resistant and dicarboximide-resistant isolates of Monilinia fructicola (Wint.) Honey in flowers, shoots and fruit of stone fruit. Plant Pathol. 44:448-457.

25. Schnabel, G., Bryson, P. K., Bridges, W. C., and Brannen, P. M. 2004. Reduced sensitivity in Monilinia fructicola to propiconazole in Georgia and implications for disease management. Plant Dis. 88:1000-1004.

26. Schnabel, G., Dai, Q., and Paradkar, M. R. 2003. Cloning and expression analysis of the ATP-binding cassette transporter gene MFABC1 and the alternative oxidase gene MfAOX1 from Monilinia fructicola. Pest Manage. Sci. 59:1143-1151.

27. Sonoda, R. M., Ogawa, J. M., Manji, B. T., Shabi, E., and Rough, D. 1983. Factors affecting control of blossom blight in a peach orchard with low level benomyl-resistant Monilinia fructicola. Plant Dis. 67:681-684.

28. Szkolnik, M., and Gilpatrick, J. D. 1977. Tolerance of Monilinia fructicola to benomyl in western New York State orchards. Plant Dis. Rep. 61:654657.

29. Villani, S. M., and Cox, K. D. 2008. QoI sensitivity and the prevalence of DMI resistance in NY populations of the brown rot pathogen Monilinia fructicola. (Abstr.) Phytopathology 98:S163.

30. Wilcox, W. F., and Burr, J. A. 1994. Base-line sensitivity of Monilinia fructicola to six DMI fungicides. (Abstr.) Phytopathology 84:S1078.

31. Yoshimura, M. A., Luo, Y., Ma, Z., and Michailides, T. J. 2004. Sensitivity of Monilinia fructicola from stone fruit to thiophanate-methyl, iprodione, and tebuconazole. Plant Dis. 88:373-378.

32. Zehr, E. I., Luszcz, L. A., Olein, W. C., Newall, W. C., and Toler, J. E. 1999. Reduced sensitivity in Monilinia fructicola to propiconazole following prolonged exposure in peach orchards. Plant Dis. 83:913-916.

33. Zhang, Z., Zhu, Z., Ma, Z., and Li, H.. 2009. A molecular mechanism of azoxystrobin resistance in Penicillium digitatum UV mutants and a PCRbased assay for detection of azoxystrobin-resistant strains in packing- or store-house isolates. Int. J. Food Microbiol. 131:157-161.

34. Zhu, F. X., Amiri, A, Bryson, P. K., and Schnabel, G. 2010. First report of the beta tubulin E198A allele for fungicide resistance in Monilinia fructicola from South Carolina. Plant Dis. 94:1511. 